\title{
Theological reflection, divorced from the incarnational nature of the Christian faith, invalidates the Bible
}

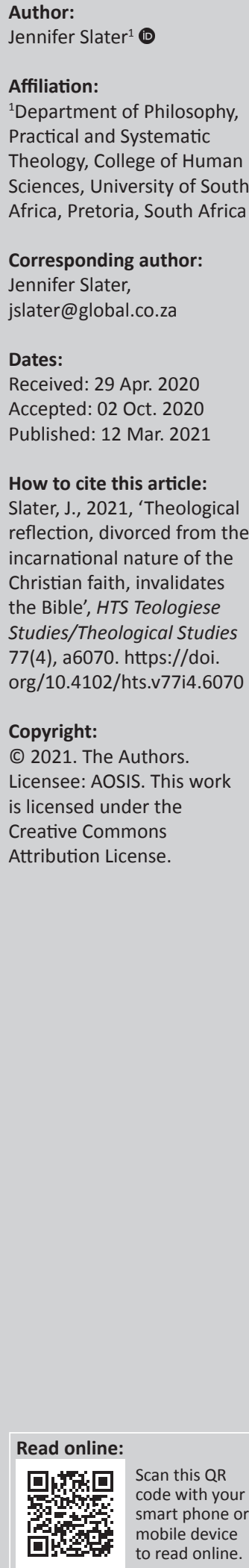

This article draws its inspiration from the famous excerpt of the 5th century Father and Doctor of the Roman Catholic Church, Jerome, who firmly claims in his Commentary on Isaiah (Nn 1.2: CCL 73,1-3) that ignorance of Scripture is ignorance of Christ. By this exhortation he urged Christians to recognise the serious necessity to study the Word of God as it is not an optional luxury to be used and interpreted with tawdriness. The secret of this renowned biblical scholar was to adhere to a fundamental criterion, namely, to interpret the Holy Scriptures in harmony with the Roman Catholic Church's magisterium, and thus no person is at liberty to interpret the scriptures alone and slip into self-righteous error. Jerome believed that the authentic interpretation of Scripture is harmonious with the faith of the (Catholic) Church and when 'correctly attuned', only then the reader is authorised to understand Sacred Scripture. Scripture is the foundation of theological truth and this article endeavours to disclose that when the bible is not perceived as an inexhaustible source of inspiration and guidance, it is left open for distasteful interpretations and becomes a recipe for scripture twisting. Relevant and engaging theology is biblically connected and when theological reflection is not embedded in the biblical narrative and contemporary life, Scripture is invalidated. Hence, Jerome cautioned: '[ $r$ ]emain firmly attached to the traditional doctrine that you have been taught, so that you can preach according to right doctrine and refute those who contradict it' (Eph 52, 7).

Contribution: The point of departure of this article is that for Christians Scripture is the foundation of theological truth. Its contribution lays in the art of authentic scripture interpretation and by so doing the scholar keeps trend with the Christian faith and precludes complacent error.

Keywords: Sacred Scripture; Sacred Tradition; magisterium; analogy of faith; literal sense; spiritual sense; interpretation.

\section{Introduction}

The study of Sacred Scripture and the authentic interpretation thereof cannot be of more significance today when scripture, the Word of God, is used to exploit uninformed and vulnerable people in a manner that demeans their humanity and undermines their search for piety. The famous saying of St. Jerome in his Commentary on Isaiah (Nn 1.2: CCL 73, 1-3), ${ }^{1}$ whereby he insists that ignorance of Scripture is ignorance of Christ, is a strong exhortation to Christians concerning the obligation for knowledgeable studies of the Holy Scriptures as a requirement for sound preaching and teaching of the Word of God. Without informed biblical knowledge, the integrity of biblical interpretation is at the mercy of abusive vendors of the Divine Word of God. This article advocates for the need of a Christian authority that keeps biblical interpreters and preachers accountable to correct biblical exposition. St. Paul vis-à-vis Holy Scripture proclaimed in his second letter to 2 Tim 3:16-17:

All scripture is inspired by God and useful for refuting error, for guiding people's lives and teaching them to be upright. This is how someone who is dedicated to God becomes fully equipped and ready for any good work.

For this reason, this article examines the role of magisterium, the teaching authority in the Roman Catholic tradition and the authority that is tasked to provide authentic and reliable interpretation of the Word of God, irrespective of whether it is in written form or to the church in the form of oral tradition handed on. The sound knowledge and interpretation of scripture is the foundation of honourable theological truth; if not, it is left completely open for distasteful and harmful interpretations. This article takes the liberty to examine how the Bible, as an inexhaustible source 1.St. Jerome's Commentary on Isaiah (Nn 1.2: CCL 73, 1-3) Office of Readings for the Feast of St. Jerome on September 30 
of challenge, inspiration and guidance, is undermined, weakened and destabilised by defective and ill-informed interpreters and preachers of the Word of God and hence accentuates the necessity of an active, inclusive biblical teaching authority (similar to the Catholic magisterium) that could call irresponsible users of the Word of God to accountability.

\section{The interpretation of Holy Scriptures in harmony with the magisterium}

The distinguished biblical scholar, Jerome, always adhered to a fundamental practice, namely, to interpret the Holy Scriptures in harmony with the magisterium of the Catholic Church. This custom safeguarded his work as he was of opinion that no person, however, scholarly and learned, was at liberty to interpret the Holy Scriptures alone and by singular independent authority because by so doing, the person is liable to slip into self-righteous error, practise spiritual abuse, mislead people and violate their religious beliefs.

The Second Vatican Council document, the Dogmatic Constitution on Divine Revelation (Dei Verbum), highlights the responsibility to authentically interpret the Word of God and this task has been:

[E]ntrusted exclusively to the living teaching office of the Church, whose authority is exercised in the name of Jesus Christ. This teaching office is not above the Word of God, but serves it, teaching only what has been handed on ... with the help of the Holy Spirit: it draws from this one deposit of faith everything which it presents for belief as divinely revealed. (DV 10: Second Vatican Council [II])

The Catholic Church's teaching authority, also known as the magisterium, is the guardian and the authentic interpreter of this divinely revealed truth (Tobin 2016:1). Until the Second Vatican Council (1962-1965), for fear of the misinterpretation of the Word of God, Catholics were on the whole not 'encouraged' to read and interpret the Bible freely and without guidance. Instead, they read the Baltimore Catechism to obtain information and instruction on Catholic doctrine. Several clergies were afraid of putting the Bible into the hands of the so-called 'simple laity' in case they would misinterpret it. Scripture was read and expounded at the Mass and during instructions for the reception of the sacraments. Thankfully, since the Second Vatican Council all this has changed and now Church leaders strongly advocate that the faithful should read the Bible for spiritual nourishment and join biblical study groups in order to enlighten their understanding and appreciation of the inexhaustible riches of the Word of God (Tobin 2016:1). Much had been performed to educate the laity, but always with proficient and informed teaching personnel at the helm of the task. For this reason, the Second Vatican Council provided instructions and guidelines regarding how the interpretation of the Holy Scriptures is to be conducted and this concerns everyone: ordained clergy and laity alike.

\section{Interpretation instructions towards the Living Word of God}

Christian tradition has always believed in the divine origin of the scriptures and observed the Bible as a trustworthy account of God's revelation to humanity written under the impulse and guidance of the Holy Spirit (Haffner 2006:90). Inspiration denotes the supernatural influence of the Holy Spirit under which the Bible was written. In Greek, theopneustos [inspiration] can be translated to 'God-breathed' and hence the understanding that scripture is the product of the 'breath of God' (Haffner 2006:91). The Holy Spirit is, therefore, the principal author who illuminates the mind and moves the will of the sacred writers to write freely. Inspiration guarantees the reliability of truth and whatever the Bible teaches, God 'teaches' because ultimately God is the 'principal author'. In this sense, inspiration under the guidance of the Holy Spirit also guarantees the durability of truth despite changing circumstances.

So when it comes to understanding and appreciating Scripture, all of us according to Tobin (2016:2) need not only the help of the Holy Spirit but also the help of human guides. These human guides, in the Roman Catholic tradition, are obliged to be proficient in the sciences that inform biblical interpretation. Acts 8:26-31 present a most instructive account of an encounter between Philip and an Ethiopian:

Now, an angel of the Lord said to Philip, 'Go south to the road, the desert road that goes down from Jerusalem to Gaza'. So he started out and on his way, he met an Ethiopian eunuch ... This man had gone to Jerusalem to worship and on his way home was sitting in his chariot reading the Book of Isaiah the prophet. The Spirit told Philip, 'Go to that chariot and stay near it'. Then, Philip ran up to the chariot and heard the man reading Isaiah the prophet. 'Do you understand what you are reading?' Philip asked. 'How can I', he said, 'unless someone explains it to me?' So he invited Philip to come up and sit with him.

The Ethiopian humbly requested Philip to be his guide and aided by the Holy Spirit, Philip was able to break open the meaning of God's word for the Ethiopian. To this end, the Catechism of the Catholic Church instructs on the Holy Spirit as the interpreter of Scripture in the following way:

In order to discover the sacred author's intention, the reader must take into account the conditions of their time and culture, the literary genres in use at that time, and the modes of feeling, speaking, and narrating then current. For the fact is that truth is differently presented and expressed in the various types of historical writing, in prophetical and poetical texts, and in other forms of literary expression. (CCC 110; Fannery 1998: 750-765)

Dei Verbum instructs that because Sacred Scripture is inspired, an important principle of correct interpretation is that: 'Sacred Scripture must be read and interpreted in the light of the same Spirit by whom it was written' (DV 12 §); otherwise, Scripture takes on the same quality as an everyday novel. For this reason, the interpreter of Holy Scripture should develop the skill to differentiate between the 'intended meaning' and the 'apparent meaning' of the text. Dei Verbum also affirms that to interpret Scripture 
correctly, the reader must be attentive to what the human authors truly wanted to affirm and to what God wanted to reveal to us by their words (DV $12 \S 1$ ). In this sense, the art of reading and interpreting the scriptures can be challenging because the reader has to discern the meaning of a text intended by the author and distinguish it from the apparent meaning of the text. What makes this so challenging, as pointed out by Tobin (2016:2), is that sometimes the apparent meaning of a text is not the meaning intended by the author as illustrated in the Creation accounts according to Genesis 1 and 2. The apparent meaning is that God created the world in 7 days and in the exact manner described therein. However, the intention of the author was not to provide us with a scientific account of how and how long it took to create the world. The intention of the author is religious, that is, to tell us that (1) God created the world, (2) God created the world good and (3) God created man and woman in his image and likeness and God created them to be partners or helpmates in the journey of life. So if someone takes the creation account as a scientific explanation, then the interpretation thereof is jeopardised and distorted. Hence, to take it literally and not religiously would render the reader a disbeliever or a fundamentalist.

Another significant factor in the interpretation of the Holy Scriptures, specifically to assist the reader to distinguish the intended meaning of Scripture from its apparent meaning, is to separate the timeless Word of God from the culturally time bound passages of Scripture. Dei Verbum states that in order to discover the sacred authors' intention, the reader must take into account the conditions of their time and culture, the literary genres in use at that time and the modes of feeling, speaking and narrating the current circumstances:

For the fact is that truth is differently presented and expressed in the various types of historical writing, in prophetical and poetical texts, and in other forms of literary expression. (DV $12 \S 2$ )

This is illustrated in Paul's letter to the Ephesians (6:5) where Paul commands slaves to obey their masters; in 1 Timothy 2:9-15, Paul instructs how women should behave in the church. In the light of Dei Verbum, it is essential to recognise that passages like these are cultural and time bound. As pointed out by Tobin (2017a:2), when we read the Bible, we must keep in mind that there is an immense historical and cultural gap between the time when the books of the Bible were written and our current time. For this reason, it is imperative to embark on informed biblical scholarship, which assists readers of the Holy Scriptures to recognise, understand and interpret the various literary forms in which the books of the Bible are written. This holds true for the violent images that are especially present in the Old Testament. A third factor advocated by the Church in Dei Verbum is as follows: be attentive to the analogy of faith. By 'analogy of faith', we mean the coherence of the truths of faith amongst themselves and within the whole plan of Revelation (DV $12 \S 3$; CCC
114:3). The Holy Spirit who inspired the original authors to write the books of the Bible continues to guide the Church in its role as the guardian and interpreter of Scripture. Hence, Tobin (2017a:2) says that Christians do well to read Scripture within our Church community; look for her guidance and so dig deeper into the inexhaustible treasures of the Bible.

\section{Sacred Scripture - Written under the inspiration of the Holy Spirit (CCC 105)}

As mentioned above, Christians are of the belief that the Sacred Scriptures have been written down under the inspiration of the Holy Spirit and for this reason, the church teaches that it ought to be read and interpreted under the guidance of the exact same Holy Spirit. To this end, the Catechism of the Catholic Church (CCC), based on the teaching of Dei Verbum (11), stipulates that the Church:

$[R]$ elying on the faith of the apostolic age, accepts as sacred and canonical books ${ }^{2}$ of the Old and the New Testaments, whole and entire, with all their parts, on the grounds that, written under the inspiration of the Holy Spirit, they have God as their author, and have been handed on as such to the Church herself. (Vatican Council II 1998:756)

Dei Verbum (11) cites the following scripture references: John 20:31, 2 Timothy 3:16 and 2 Peter 1:19-21, 3:15-16 to substantiate the teaching that the Holy Spirit inspired the authors that we must, therefore, acknowledge that what Scripture teaches is the truth for our salvation. What needs to be clarified, however, is that the Christian faith is not a 'religion of the book'; instead, Christianity is the religion of the 'Word' of God, a Word that is 'not a written and mute word, but the Word is incarnate and living' (St. Bernard, S. missus est hom. 4,11: PL 183,86). ${ }^{3}$ The Word became flesh and lived amongst us. For this reason, the Scriptures are not a dead letter because Christ, the eternal Word of the living God, through the Holy Spirit 'opens [our] minds to understand the Scriptures' (Lk 24:45).

\section{The Holy Spirit as the interpreter of Scripture}

The Holy Spirit as the interpreter of Scripture determines the criteria of genuine interpretation. To assist with this, the Second Vatican Council, in Dei Verbum, indicates three criteria for interpreting Scripture in accordance with the Spirit who inspired it (DV $12 \S 4)$.

\footnotetext{
2.The Roman Catholic and Eastern Christian Orthodox canon contain 73 books. The extra books are called the apocrypha or deuterocanonical books. The books were originally written in Greek between 250 and 50 BC. These books are Tobit, Judith, 1 and 2 Maccabees, Wisdom of Solomon (the Book of Wisdom), Sirach (Ecclesiasticus) and Baruch with the Letter of Jeremiah as its last chapter. The Book of Daniel and the Book of Esther are longer in the Catholic Bible than in the Protestant Bible. The Roman Catholic canon dates back to 367 AD consisting of 73 books listed by St. Athanasius that he believed to be divinely inspired. This list was approved by St. Athanasius that he believed to be divinely inspired. This list was approved by Pope Damasus I in $382 \mathrm{AD}$ and formally ratified by the Church Council of Rome in 382. In 405 AD, Pope Innocent, in a letter to the Bishop of Toulouse, reaffirmed the canon of 73 books. Once again in 419 AD, the Council of Carthage restated the canon to which Pope Boniface agreed. The Council of Trent, in 1546, endorsed St. Athanasius's original list of 73 books.
} 
The first criterion is to be especially attentive 'to the content and unity of the whole Scripture'. Different as the books may be, Scripture is a unity by reason of the unity of God's plan, of which Christ Jesus is the centre and heart, open since his Passover:

The phrase 'heart of Christ' can refer to Sacred Scripture, which makes known his heart, closed before the Passion, as the Scripture was obscure. But the Scripture has been opened since the Passion; since those who from then on have understood it, consider and discern in what way the prophecies must be interpreted. (CCC 112)

The second criterion as set forward in Dei Verbum is: Read the Scripture within 'the living Tradition of the whole Church'. According to a saying of the Fathers, Sacred Scripture is written principally in the Church's heart rather than in documents and records, for the Church carries in its Tradition the living memorial of God's Word and it is the Holy Spirit who gives her the spiritual interpretation of the Scripture ('... according to the spiritual meaning which the Spirit grants to the Church' - CCC 113).

The third criterion is to be attentive to the analogy of faith. Analogy of faith means the coherence of the truths of faith amongst themselves and within the whole plan of Revelation. Pope Pius XII was instrumental in using this term when he issued his Encyclical Humani Generis at St. Peter's on 12 August 1950 concerning some false opinions threatening to undermine the foundations of Catholic doctrine. In Humani Generis, Pope Pius XII uses the term 'analogy of faith' to emphasise that Holy Scripture should be interpreted according to the mind of the Church. He was warning that Holy Scripture cannot just be interpreted without the required authority and compliance with the specified criteria for sound interpretation. In this sense, Pope Pius XII endorsed exactly what Jerome and other biblical scholars adhered to and counselled.

The New Catholic Encyclopaedia explains that the term 'analogy' originated from the mathematical term, which means 'proportion' from the Greek analogia and was borrowed by philosophers to refer to the relationship between the concepts of things that are partly the same and partly different. The New Catholic Encyclopaedia explicates that the analogy of faith [analogia fidei] ought not to be confused with the more philosophical concept. The expression 'analogy of faith' is biblical; for example, Romans 12:6 speaks about the charism of prophecy, together with similar gifts such as ministering, teaching and exhorting. Prophets generally exercised one of the several 'offices' within the primitive church (Ac 11:27, 13:1). They did so under the guidance of the Spirit and in the process, they gained insight into the faith or detected tasks to be undertaken. The Pauline directive was given so that the gift of prophecy must be exercised 'according to the proportion of faith'. It was a ruling that no prophet was to be accepted who proclaims anything that opposed the 'one faith' proper to the 'one body in Christ'. Such preaching would not be in proportion to or within the objective truth entrusted to the Christian community. It is, therefore, clear that the analogy of faith has always been associated with the one unchanging faith of the Church; it is closely related to the understanding of Tradition and soon became a yardstick for the early Christian writers. As stated by the New Catholic Encyclopaedia, they saw a 'proportion' in the manner that the New Testament complements the Old Testament and in this way each particular truth contributes to the inner unity of the entire Christian revelation.

Thus, the phrase analogia fidei came to indicate an instruction or a directive for the exegesis of Scripture. It became a norm that in complicated texts, the teachings of tradition and the analogy of faith must provide guidance. For this reason, the Catholic exegete, conscious of his or her faith, always acknowledges the intimate relationship between Scripture and Tradition; he or she strives to explain scriptural passages in such a way that the sacred writers will not be set in opposition to one another or to the faith and the teaching of the Church. This is a very important factor of accountability and the church's teaching authority (the magisterium) calls false interpretations to culpability. It is this precisely to guard against unscrupulous persons who take self-righteous liberty to interpret the scriptures alone and consequently slip into censorious error.

\section{The art of biblical interpretation takes cognisance of the different senses of Scripture}

Haffner (2006:110) affirms that the interpretation of the sacred scripture must be attentive above all to what God wants to reveal through the sacred authors of our salvation. He speaks in line with the Second Vatican Council (Dei Verbum, 9-10), which states that:

... [S]ince Holy Scripture must be read and interpreted in the sacred spirit in which it was written, no less serious attention must be given to the content and unity of the whole of Scripture if the meaning of the sacred texts is to be correctly worked out. The living tradition of the whole Church must be taken into account along with the harmony which exists between elements of the faith. It is the task of exegetes to work according to these rules toward a better understanding and explanation of the meaning of Sacred Scripture, so that through preparatory study the judgment of the Church may mature. For all of what has been said about the way of interpreting Scripture is subject finally to the judgment of the Church, which carries out the divine commission and ministry of guarding and interpreting the word of God. (Vatican Council II 1998:755)

According to the ancient tradition, as explained by the Catholic Catechism, the teachings of the 'four senses of Scripture' are important in this sense that one can distinguish between two senses of Scripture: the literal and the spiritual. The latter is subdivided into allegorical, moral (tropological) and anagogical senses. The Catechism of the Catholic Church (Par 118:57) cites a medieval couplet, which summarises these four senses: Lettera gesta docet, quid credas allegoria, moralis quid agas and quo tendas anagogia. The Letter speaks of deeds: allegory of faith; the moral how to act; anagogy our destiny. The profound concordance of the four senses 
guarantees all its richness to the living reading of Scripture in the Church (CCC 115). Biblical texts are analysed so as to synthesise the truth they contain. The Catechism (CCC) teaches that the basic distinction exists between the literal and spiritual senses of the biblical text. It states that the literal sense refers to what the human author directly intended the text to mean, whereas the spiritual sense refers to the additional meanings invested by God in the text and of which the human author may not necessarily have been aware of.

\section{The literal sense}

The literal sense, as explained by the Catechism, is 'the meaning conveyed by the words of Scripture and discovered by exegesis, following the rules of sound interpretation: "All other senses of Sacred Scripture are based on the literal"' (CCC 116, cf. ST I:1:10 ad 1). Hence, the Catholic Church teaches that the first principle of hermeneutics is the literal meaning of the text. St. Jerome (in Ezech 38:1, 41:23, 42:13) wrote that all interpretation rests on the literal sense. This was reiterated by St. Thomas Aquinas (ST 1,a.1,q 10 ad 1) who said that ' $[a] 11$ other senses of Sacred Scripture is [sic] based on the literal'. Pope Pius XIl in Divino Afflante Spiritu (23) declared:

Let the interpreters bear in mind that their foremost and greatest endeavour should be to discern and define clearly that sense of the biblical words which is called literal. Aided by the context and by comparison with similar passages, let them, therefore, by means of their knowledge of languages search out all diligence the literal meaning of the words.

Haffner (2006:112) explains that the literal sense of scripture can be defined as the meaning that the author under divine inspiration directly intended and which the author's words convey. The literal sense and meaning conveyed by the words of scripture are discovered by exegesis that follows the rules of reliable interpretation. He goes on to state that a useful criterion to understand the literal sense is to determine the literary form used by the author. If, for example, the author uses poetry instead of history, then the literary form of poetry will help in establishing the meaning that was intended by the author and so would any other literary forms, such as history, law, songs, parables, etc.

It is, therefore, important to keep the balance between the literal and spiritual senses when biblical texts are interpreted. Hence, the Catechism calls to attention the primacy of the literal sense as the foundation of sound interpretation. The schooled exegete will know how to discern the literal sense and to apply reliable rules of interpretation. The starting point is the words of Scripture themselves. It is known that fundamentalist interpreters often oppose the idea that there is a spiritual sense in a text and display a marked preference for the literal reading. The trained exegete will always discern what the author of the text in all likelihood intended when he or she wrote what he or she did write. This sense is often assigned to biblical exegesis as an academic discipline.

\section{The spiritual sense}

By definition, the spiritual sense of a text implies something deeper than what can be obtained from a verbal reading thereof. To discern the spiritual sense involves looking past the text itself to the people, the culture and events it narrates. Hence, the Catholic Catechism notes: ' $[t]$ hanks to the unity of God's plan, not only the text of Scripture, but also the realities and events about which it speaks can be signs' (CCC 117). In other words, the selection of certain things for inclusion in Scripture points towards other spiritual realities that are part of God's plan.

As mentioned above, the Catholic Catechism (CCC 117) indicates three subdivisions under the Spiritual sense for interpreting the scriptures in accordance with the Spirit who inspired it. These are:

1. The allegorical sense: We can acquire a more profound understanding of events by recognising their significance in Christ; thus, the crossing of the Red Sea in the Old Testament is later interpreted in the New Testament as a sign or type of Christ's victory and also of Christian Baptism (1 Cor 10:2). The deed connected with allegory is faith.

2. The moral sense: The events reported in Scripture ought to lead us to act justly. As St. Paul says, they were written 'for our instruction' (1 Cor 10:11). The deed attached to moral is how to act.

3. The anagogical sense (from Greek anagoge, meaning 'leading'): We can view realities and events in terms of their eternal significance, leading us towards our true homeland. Thus, the Church on earth is a sign of the heavenly Jerusalem ( $\operatorname{Rev} 21: 1-22: 5)$. The deed related to anagogy is destiny.

These three divisions have their own challenges when interpreting the Scriptures. According to Akin (2004), to read the moral messages from Scripture can be tricky, but fairly non-controversial. However, the other two traditional divisions of the spiritual sense, namely, the allegorical and the anagogical, prove to be much more contentious. The reason is that in these cases, the meaning of the scriptures seems to go far beyond that which the author envisioned. Yet, New Testament authors such as Paul clearly drew out such meanings.

It is apparent from the study of languages (as advocated by the Catholic Church) that allegorical and typical senses possess two basic figures, namely, simile and metaphor. An example of a simile is, Jesus sends out his disciples as lambs amongst the wolves (Lk 10:3). In the use of metaphor, Jesus said: 'You are the salt of the earth' (Mt 5:13). Parables are perceived as a developed simile, whereas allegory is a developed metaphor or a series of metaphors, less clear, and more elusive than a parable because it possesses hidden meanings as in Mark 4:1-20. Typology ${ }^{4}$ in biblical texts

4.Typology (a special kind of symbolism) is regarded as a method of biblical interpretation seen the prefigure the ful found in the called type and the fulfilment thereof is called the antitype. The type or the antitype can be anything from a person, and event, but often the type is messianic and often related to some or other idea of salvation. Typological interpretation is based on finding a connection between the Old Testament and New Testament whereby the Old Testament prefigures what will occur in the New Testament. 
presents a deeper meaning that some elements such as people, places, things and events in the Bible have because God, the divine author of the Bible, intended that these elements foreshadow such as the crossing of the Red Sea (Haffner 2006:122).

The allegorical method of reading the Old Testament was familiar to the Jews and the early Christians as the latter inherited this tradition from late Judaism. They saw allegorical meanings in the pages of Scripture that exceeded what the words of the text conveyed. To illustrate this, in Galatians 4:21-31, Paul draws an analogy between the Old and the New Covenants and Abraham's wives Sarah and Hagar. The concubine Hagar was a slave and Paul saw in her an appropriate image of the bondage of the Old Covenant, whilst he found in Sarah the free woman, a fitting symbol of the liberty of Christ (Akin 2004). If one was to read the text of Genesis and adhered to it in a literal sense, there would be no conclusion that Sarah and Hagar symbolised two covenants. The same goes for Romans 5:14 where Paul perceived Adam as a type of the one who is to come, that is, Christ. The Old Adam and the New Adam developed the Christian biblical interpretation of typology, whereby Old Testament types could be seen as images of New Testament antitypes. Hence, Christians started to recognise more than one sense in the sacred text: the sense of what the text itself says and a greater sense that goes beyond this. Considering the allegorical sense, the Catechism notes:

We can acquire a more profound understanding of events by recognising their significance in Christ; thus the crossing of the Red Sea is a sign or type of Christ's victory and also of Christian Baptism. (CCC 117)

Biblical scholars assign this sense to systematic theology as its academic domain.

The moral sense is also referred to as the tropological sense (from the Greek word trepein, meaning 'to turn') that 'turns' the meaning back on the reader to apply it to one's own life. St. Thomas says:

[S]o far as the things done in Christ, or so far as the things which signify Christ, are types of what we ought to do, there is the moral sense. (St Thomas Aquinas STh I, 1, 10 CCC 1994:56)

According to the Catholic Catechism, the moral sense notes that 'the events reported in Scripture ought to lead us to act justly. As St. Paul says, they were written "for our instruction"' (1 Cor 10:11). In this text, Paul is discoursing passages from the Pentateuch when the Israelites sinned and were subsequently punished by God. He then says, ' $n$ ]ow these things happened to them as a warning, but they were written down for our instruction, upon whom the end of the ages has come'. In this instance, Paul recognises the moral sense of the text, that is, when we sin, we are liable to be punished. In this instance, the message also goes beyond what the words convey, but it is nevertheless apparent that the author intended the very message to be understood by his readers. In addition, the parables have edifying moral lessons, which we ought to 'turn' upon ourselves. To illustrate this in practical terms, one would ask oneself whether I am that priest or Levite who disregarded the poor unfortunate on the way to Jericho or am I like the prodigal son's older brother, who was resentful of the good treatment that his repentant brother received? The tropological sense corresponds to the academic discipline of moral theology.

The third subdivision, the anagogical sense, as denoted by the Catechism, is based on Revelation 21:1-22:5: 'we can view realities and events in terms of their eternal significance, leading us towards our true homeland: thus the Church on earth is a sign of the heavenly Jerusalem'. This sense interprets the things in Holy Scripture 'as they signify what relates to eternal glory'. This meaning of course is restricted not only to the glorious state in Heaven but also to the contemplative participation in the heavenly or spiritual realities here and now. In Isaiah 66:10-11, I rejoiced at the things that were said to me: we shall go into the house of the Lord. Our minds and hearts are lifted to the "heavenly [or "new"] Jerusalem. Rev. 3:12; 21:2; Heb. 12:22'. This illustrated the anagogical sense that the destiny is held in sight. Other examples of the anagogical sense would include the parables of the wedding feast (Mt 22). Here, the happiness of heaven is symbolised by the banquet, which also typifies the eternal matrimonies of Christ with his bride, the Church. The parables of the 10 virgins and that of the talents, related in Matthew 25, have obvious anagogical interpretations of the four last things. ${ }^{5}$ This is related to the description of the final judgement and the eschatological discourse of Jesus in Matthew 24.

Whilst both the allegorical and the anagogical senses involve typology, there is however a key difference between them. The difference relates to whether we are living before or after the antitype that the sign points towards. It is clear that the fourfold interpretation assists interpreters to draw out major theological insights and teachings, such as dogmatic, moral, ascetical and mystical theology, from the inspired texts. By using the analogy of faith, it shows that scripture is not an isolated subject, but connected to theology and Christian living. This coincides with John 20:31, '[b]ut these are written that you may believe $[a]$ that Jesus is the Messiah, the Son of God, and that by believing you may have life in his name'.

These subdivisions of the spiritual sense are often perceived as arbitrary because there are other ways in which it could be

5.The Four Last things form part of Christian eschatology based on the Profession of the Christian Faith (Art 12) 'I believe in life everlasting', which forms part of both the Apostolic and Nicene Creed. The last four things (quattuor novissima in Latin) pertain to death, Judgement, heaven/hell and the afterlife.

Death: The Christian who unites his own death to that of Jesus views it as a step towards him and an entrance into everlasting life ...

Judgement: Death puts an end to human life as the time open to either accepting or rejecting the divine grace manifested in Christ. The New Testament speaks about judgement primarily not only in its aspect of the final encounter with Christ in his second coming but also repeatedly affirms that each will be rewarded immediately after death in accordance with his works and faith.

Heaven: Those who die in God's grace and friendship and are perfectly purified live forever with Christ. They are like God forever, for they 'see him as he is', 'face to face'.

Purification: All who die in God's grace and friendship, but still imperfectly purified, are indeed assured of their eternal salvation, but after death they undergo purification so as to achieve the holiness necessary to enter the joy of heaven.

Hell: We cannot be united with God unless we freely choose to love him. But we cannot love God if we sin gravely against him, against our neighbour or against ourselves.

Afterlife: He who does not love remains in death (CCC 1020-1062). 
divided and so too with the literal sense. In fact, Thomas Aquinas in his Summa Theologiae considered a number of possible subdivisions for the literal sense (cf. ST I:1:10). The Catechism is not in conflict but asserts that 'according to an ancient tradition, one can distinguish' the four senses as we have them; however, it did not say that this is the only way to divide the meanings of Scripture. It is a traditional way of doing so and a noteworthy and useful way of doing so, but not the only one (Akin 2004).

\section{Abuse of the four senses is an abuse of scripture}

Whilst many Christian scholars can accept that Paul or the authors of the Gospels draw out typological meanings from the Old Testament, many are concerned about the probability of allowing non-aligned, self-contained interpreters to draw out their own meanings. The question is, 'what limits would keep interpreters from drawing out all kinds of outrageous meanings, something that is very common in history and in our current times?' It is for this reason that being accountable to a magisterium is highly beneficial. To be free of the pressures created by sola scriptura to adhere only to the meanings that can be drawn directly from the verbal sense of the text and to be guided by limiting factors such as tradition and the teachings of the magisterium, do Catholics find themselves in a securer position? In this regard, it appears that they have been more comfortable to follow the example of the apostles than discerning the allegorical and anagogical meanings present in the Scriptures. In instances like this, the teaching authority, such as the magisterium, safeguards against extreme and fanatical interpretation because scripture and tradition for Roman Catholics constitute a single sacred deposit of the Word of God, entrusted to the church with utmost divine responsibility. This does not imply that the Catholic use of spiritual exegesis is exempt from difficulties. In their eagerness to investigate the spiritual sense of a text, Catholics examine large quantity of meanings and often some of these meanings go together with uncertainty. Because tradition speaks about the four senses of Scripture, Catholics sometimes function under the supposition that every biblical passage must contain each of the senses, which is not always the case. At other times, Catholic exegetes forget to abide by the concrete principles, whereby spiritual interpretations may be drawn, that is:

- when the literal sense ought to be recognised as the primary sense

- the proposed spiritual meanings should not contradict the literal sense

- the spiritual meaning is not used to establish, but only to elucidate doctrine.

This was often the situation with Apologists who overlooked the last principle, particularly on the subject of Mary, the Mother of Jesus. The reason, understandably so, is that Mariology is not always explicit in Scripture, but only alluded to (Akin 2004):

Out of a desire to provide an explicit warrant for Marian teachings, apologists have a temptation to turn to the spiritual sense of various texts, sometimes placing so much emphasis on it that they lose sight of the literal sense of the passage. (https://www. catholic.com/magazine/print-edition/one-text-four-senses)

This is where Thomas Aquinas expressed many warnings stating that a multiplicity of senses could cause confusion and destroy the strength of theological argument. He wrote:

In Holy Writ no confusion results, for all the senses are founded on one - the literal - from which alone can any argument be drawn, and not from those intended in allegory. (ST I:1:10 ad 1)

Following Aquinas, Catholic exegetical tradition has recognised that doctrine can be founded only on the literal sense of a passage. The function of the spiritual sense is to illuminate doctrine, but not to prove it. A better approach is to admit the confines of what can be proven from the literal sense and simply acknowledge that not every article of the Christian faith can be proven from Scripture alone. For this reason, the magisterium still teaches the medieval couplet that summarises the significance of the four senses:

The Letter speaks of deeds; Allegory to faith; the Moral how to act; Anagogy our destiny. (CCC 118)

\section{The Catechism (119) based on Dei Verbum states that:}

$[I] \mathrm{t}$ is the task of exegetes to work, according to these rules, towards a better understanding and explanation of the meaning of Sacred Scripture in order that their research may help the Church to form a firmer judgement. For, of course, all that has been said about the manner of interpreting Scripture is ultimately subject to the judgement of the Church, which exercises the divinely conferred commission and ministry of watching over and interpreting the Word of God. (DV 88)

To this end, the Catechism quotes St. Augustine: '[b]ut I would not believe in the Gospel, had not the authority of the Catholic Church already moved me' (Contra epistolam Manichaei). The authority of the church (the magisterium) is housed in the living tradition of the entire church and the Sacred Scripture has to be read within the Sacred Tradition.

\section{Scripture has to be read within 'the living tradition of the whole church'}

The Catholic Catechism (76) teaches that Christ the Lord, in whom the entire Revelation of the Most High God is summed up, commanded the apostles to preach the Gospel. In keeping with the Lord's command, the Catholic Catechism continues by stating that the Gospel was handed on in two ways:

- orally 'by the apostles who handed on, by the spoken word of their preaching, by the example they gave, by the institutions they established, what they themselves had received - whether from the lips of Christ, from his way of life and his works, or whether they had learned it at the prompting of the Holy Spirit'

- in writing 'by those apostles and other men associated with the apostles who, under the inspiration of the same Holy Spirit, committed the message of salvation to writing'. (CCC 1994:49) 
What the apostles handed on, either by the spoken word of their preaching or by the example they gave, is known as the Apostolic Tradition. The term Sacred Tradition, as used in connection with the Church, is often misunderstood, especially amongst Christians who have what is called a 'Bible only' approach to what God has revealed to us. Yet, to understand Tradition and its role in the transmission and interpretation of Divine Revelation is extremely important. Many Christians who follow the 'Bible only' approach do not acknowledge the role of Sacred Tradition in the transmission and interpretation of divinely revealed truth. In contrast, for Catholic Christians, 'Sacred Tradition and Sacred Scripture are like a mirror in which the pilgrim church on earth looks at God, from whom she has received everything' (DV \#7).

The word 'Tradition' literally means 'what is handed on'. Tradition refers to the process by which the message of Christ is transmitted from one generation to another. In ancient Christianity, the transmission of God's Word occurred through the oral preaching of the Apostles, through the communal and worship life of the first Christians and through anything that contributed to the sanctification of the people (Dogmatic Constitution of Divine Revelation [DV] \#8). In the early decades of Christianity, the Word of God (Divine Revelation) was not transmitted in written form because the books of the New Testament were not yet written. It is recorded that the writings of the New Testament Canon commenced with the Letter of James between 45 and 50 AD and ended with the Book of Revelation in 95 AD. Hence, the first books of the New Testament were not written until 20 years after the death of Jesus. The 27 books of the New Testament were not completed in written form until the end of the 1st century and the Canon of Scripture was not decided until the 4th century (ed. Livingstone 1990:88). After they were written, they were not available to all the Christian communities, and they were not intended to contain all that Jesus said and did. John ends his gospel with these words:

There are many other things that Jesus did, but if they were to be described individually, I do not think that the whole world would contain the books that would be written. (Jn 21:25)

When the books of the New Testament were written, they became an invaluable and infallible source of Divine Revelation. However, Divine Revelation also continued to be passed on orally and in the communal worship of the Church. In his second letter to the Thessalonians, Paul wrote: '[h]old the teachings that you have learned, whether by word or letter of ours' (2 Th 2:15). When the term 'Tradition' is used in the context of the early decades of Christianity, it is referred to as the Apostolic Tradition because of its closeness to the time of the Apostles. In time, Sacred Tradition came to include the writings of the early Church Fathers. These writings are very important for a true and authentic understanding of God's Word (both oral and written) because these men lived and wrote in the generations after the apostles. They were the recipients of what we called above Apostolic Tradition. They wrote and interpreted it for the people of their time. We can safely say that any interpretation of God's Word that ignores the writings of the early Church Fathers is on shaky ground.
It is essential to grasp that the creedal statements of faith delivered after the deliberations of the early Church councils, also, form an integral part of Sacred Tradition. When aspects of Christian belief were erroneously or falsely interpreted, the Church formulated creedal statements of faith, such as the Nicene Creed (19 June 325) and the Apostles' Creed (390 AD) and these creedal statements helped the faithful to steer clear of false teachings and profess what was true doctrine (Tobin 2017b:3).

To further understand Sacred Tradition, it needs to be distinguished from human traditions (sometimes called tradition with a small ' $t$ '). The latter refers to man-made rules, customs and practices that are connected to core teachings of the Church, but are not in themselves core Church teachings. For example, Catholic belief in the real presence of Jesus in the bread and wine at Mass is a core Church teaching that cannot be changed. This belief is based on scripture (1 Cor 11:24) and on the words of Jesus according to Matthew 24:24, '[w]hilst they were eating, Jesus took bread, and when he had given thanks, he broke it and gave it to his disciples, saying: "Take and eat; this is my body". However, the manner in which the Mass is celebrated belongs to human tradition. It can change from one generation to another. The Mass can be said in Latin or in the vernacular of the people. People can receive Holy Communion in their hand or on their tongue. According to the Roman Catholic teachings, the sacrament of Holy Orders belongs to Tradition with a large ' $\mathrm{T}$ ' and the Church has no authority to state that it will no longer have this sacrament, although the practice of mandatory celibacy for all seeking ordination is a human tradition and thus belongs to tradition with a small ' $t$ '. The Church could and has ordained married men. When Jesus condemned traditions in the Bible (Mt 23), he was condemning human traditions that were an obstacle rather than a help to people in their relationship with God.

The Catholic understanding of Tradition, therefore, not only refers to a set of Christian beliefs received from the past but also refers to how the Church throughout the centuries has, through prayer and study, grown in its understanding of what is passed on and handed down from one generation to another. This growth in understanding has always been a 'growth from partial to fuller vision, so what was believed, continues to be believed, though its depths and consequences are more fully realized' (Tobin 2017b:3). Each of us personally participates in this growth in understanding of our Catholic faith whenever we take time to study and contemplate it (Tobin 2017b:3).

Vatican Council II and the following years witnessed a wonderful experience of growth in understanding the Sacred Tradition. At the Council, the bishops aided by brilliant and dedicated theologians (who all acted under the guidance of the Holy Spirit) came to an in-depth understanding of every aspect of the Church's life. It is very important to note that for Catholics, nothing in Tradition can be contrary to what is contained in the Bible. In fact, the Church must often examine its beliefs and practices in the light of Sacred Scripture. 
Having said that, it is also important to note that for Catholics, a belief or practice is only considered non-scriptural if it contradicts or is not in harmony with Scripture. For example, the pastoral practice of baptising infants is not explicitly stated in the Bible, but neither is it forbidden. It is implied in Acts that speaks about whole households being baptised (Ac 16:33).

\section{The relationship between Sacred Tradition and Sacred Scripture}

The second Vatican Council taught explicitly that Sacred Tradition and Sacred Scripture form one sacred deposit of the Word of God, committed to the Church in Dei Verbum (n10). Sacred Tradition and Sacred Scripture have a common source and thus they are bound closely together and communicate with one another. 'For both of them, flowing out from the same divine wellspring, come together in some fashion to form one thing and move towards the same goal' (DV 9). Each of them makes present and fruitful in the Church the mystery of Christ, who promised to remain with his own 'always, to the close of the age' (Mt 28:20). The two have two distinct modes of transmission:

81 Sacred Scripture is the speech of God as it is put down in writing under the breath of the Holy Spirit.

And [Holy] Tradition transmits in its entirety the Word of God which has been entrusted to the apostles by Christ the Lord and the Holy Spirit. It transmits it to the successors of the apostles so that, enlightened by the Spirit of truth, they may faithfully preserve, expound and spread it abroad by their preaching. (Mt 28:20)

82 As a result the Church, to whom the transmission and interpretation of Revelation are entrusted, does not derive her certainty about all revealed truths from the holy Scriptures alone. Both Scripture and Tradition must be accepted and honoured with equal sentiments of devotion and reverence. (CCC)

Senior (2018:17), in reflecting on the life of Raymond Brown, the renowned 20th century Catholic biblical scholar, who spearheaded the dynamic Catholic biblical renewal, reiterated the invaluable contribution made by the Second Vatican Council towards Biblical Scholarship. He stated, '[r]ather than portraying Scripture and Tradition as two separate conduits of revelation, the Council saw both Scripture and Tradition as 'bound together, and communicating one with the other' (DV 9). 'Sacred Tradition and sacred Scripture make up a single sacred deposit of the Word of God, which is entrusted to the Church' (DV 10). He pointed out that this formulation not only ratified the teaching authority of the church but also made it accountable to Scripture. The church is, therefore, viewed as both the servant of the Word and its authentic interpreter. Vatican II presented the entirety of the Scriptures, both the Old Testament and the New Testament, as the privileged and inspired transmission of this divine revelation. This transmission of the Word of God was entrusted to the apostles by the risen Christ and continues in the apostolic church founded in his name until the end of time. He affirms that this overall portrayal of divine revelation enabled Vatican II to address in a fresh way several key issues of great importance for the interpretation of Scripture within the church.
Senior (2018:17) further clarifies the Council's affirmation that the Scriptures whilst divinely inspired were, nevertheless, composed by human authors, with all the conditions required for the composition of any literature within its own linguistic, cultural and historical contexts. He quotes Dei Verbum no. 12:

Hence the exegete must look for that meaning which the sacred writer, in a determined situation and given the circumstances of his time and culture, intended to express and did in fact express, through the medium of a contemporary literary form. Rightly to understand what the sacred author wanted to affirm in his work, due attention must be paid both to the customary and characteristic patterns of perception, speech and narrative which prevailed at the age of the sacred writer, and to the conventions which the people of his time followed in their dealings with one another. (Vatican Council II 1998:757)

This is where the magisterium plays a role in deciding authoritatively with the establishment of the Pontifical Biblical Commission whose truths form a part of sacred tradition.

\section{The magisterium}

85 'The task of giving an authentic interpretation of the Word of God, whether in its written form or in the form of Tradition, has been entrusted to the living teaching office of the Church alone. Its authority in this matter is exercised in the name of Jesus Christ'. This means that the task of interpretation has been entrusted to the bishops in communion with the successor of Peter, the Bishop of Rome.

86 Yet this Magisterium is not superior to the Word of God, but is its servant. It teaches only what has been handed on to it. At the divine command and with the help of the Holy Spirit, it listens to this devotedly, guards it with dedication and expounds it faithfully. All that it proposes for belief as being divinely revealed is drawn from this single deposit of faith.

87 Mindful of Christ's words to his apostles: 'He who hears you, hears me', the faithful receive with docility the teachings and directives that their pastors give them in different forms. (CCC)

\section{The role of the Church as the protector and interpreter of God's Word}

When it comes to the transmission and interpretation of Divine Revelation, the role of the Church is to be the protector and interpreter of God's Word. It can be said that the Church's role is twofold: to protect the deposit of faith from false and erroneous interpretations (Ac 20:28-32) and to draw forth an in-depth understanding of the spiritual treasures found in Divine Revelation. When it comes to the Church protecting the deposit of faith from false interpretations and discovering its rich treasure, the lay faithful, theologians and the Church's magisterium each have a valuable role to play. Catholics believe that the Holy Spirit enables the bishops in union with the pope to recognise God's Revelation. The magisterium is a living source of discernment for our Church family. When it comes to the protection and interpretation of Divine Revelation and the life of the Church, the role of the magisterium (the bishops' teaching in union with the pope) 
is that of a watchdog of orthodoxy (right belief). Catholics, however, do not refer exclusively to the Bible in a purely individual way; they read the Bible under the guidance of the Church (which has the divine promise of being guided by the Holy Spirit) and according to its interpretation (Tradition), because the Church came before the Bible (as a combination of the Old Testament and New Testament).

\section{Conclusion}

The Bible remains an inexhaustible source of challenge, inspiration and guidance. This article intended to reemphasise the sentiment of St. Jerome, who stated that an authentic interpretation of the Bible must always be in harmony with the faith of the (Catholic) Church. He was of firm belief that ignorance of Scripture is ignorance of Christ and to interpret the scriptures with unscrupulous liberty and with no accountability to some form of church authority inevitably leads to self-righteous error. His exhortation to study the Word of God is most critical today as uninformed interpretations of the Bible lead to undermining the faith of righteous people. When the art of interpreting the Bible is merely an academic exercise, divorced from the faith of the church and people, it is left open for distasteful and harmful interpretations. Scripture twisting is a common practice amongst interpreters who harbour personal agendas or are in great need of self-aggrandisement, be it financially or intellectually. If any interpretation is divorced from biblical and theological truth, divine inspiration and guidance, it leads to repugnant teachings and beliefs. These reckless practices invalidate the sacredness of scripture and the sanctity of tradition. It also violated the sanctity of people's beliefs and religious doctrines. It is morally sensible to head to Jerome's counsel when he said that interpreters of the Holy Scriptures need to ' $r$ ] emain firmly attached to the traditional doctrine that you have been taught, so that you can preach according to right doctrine and refute those who contradict it' (Eph 52,7).

\section{Acknowledgements Competing interests}

The authors have declared that no competing interest exist.

\section{Author's contribution}

I declare that I am the sole author of this research article.

\section{Ethical considerations}

This article followed all ethical standards for a research without direct contact with human or animal subjects.

\section{Funding information}

This research received no specific grant from any funding agency in the public, commercial or not-for-profit sectors.

\section{Data availability}

Data sharing is not applicable to this article as no new data were created or analysed in this study.

\section{Disclaimer}

The views and opinions expressed in this article are those of the author and do not necessarily reflect the official policy or position of any affiliated agency of the author.

\section{References}

Akin, J., 2004, One text, four senses: Understanding the distinctions between the literal and spiritual senses of the Bible, Catholic Answers: to explain and defend the faith (1996-2020), viewed 29 November 2020, from https://www.catholic.com/ magazine/print-edition/one-text-four-senses.

Aquinas, T., 2007, Summa Theologiae (ST I:1:10), transl. Dominican Province, Republished in 2007, Forgotten Books, New York, NY.

Flannery, A., 1998, Vatican Council II: The Dogmatic Constitution on Divine Revelation (Dei Verbum), Article 2, The Transmission of Divine Revelation, in A. Flannery (ed.), Dominican Publications, Dublin.

Haffner, P., 2006, New Testament theology: An introduction, Millstream Production, Rome.

Jerome's Commentary on Isaiah (Nn 1.2: CCL 7213 ), 1974, Office of Readings for the Feast of St Jerome on September 30, The Divine Office, The Liturgy of the Hours according to the Roman Rite, Talbot, Dublin.

Livingstone, E.A. (ed.), 1990, The concise Oxford Dictionary of the Christian church, Oxford University Press, Oxford.

Pope Pius XII, 1943, Divino Afflante Spiritu. Encyclical of Pope Pius XII On Promoting Biblical Studies, Commemorating The Fiftieth Anniversary of Providentissimus Deus to our Venerable Brethren, Patriarchs, Archbishops, and other Loca ordinaries enjoying peace and communion with the Apostolic See, Vatican City Press, Rome.

Pope Pius XII, 1950, Encyclical Humani Generis of the Holy Father Pius XII, Libreria Editrice Vaticana, Rome.

Senior, D., 2018, Raymond Brown and the Catholic Biblical Renewal, Paulist Press, Malwah, NJ.

The Catechism of the Catholic Church (CCC), 1994, Libreria Editrice, Paulines Publications, Vatican City.

The New Catholic Encyclopaedia, 2003, The Catholic University of America, Gale Group, Farmington Hill MI, viewed 26 May 2020, from http://www.gale.com.

Tobin, E., 2016, Sacred scripture, sacred tradition and the church - Fr. Eamon Tobin (c) Ascension Catholic Church Melbourne, FL, tobin2@live.com, viewed n.d., from http://www.ascensioncatholic.net/.

Tobin, E., 2017a, Divine Revelation and our faith response (Rcia) (C 50 100, 142184 USC Ch. 1,2,4), Ascension Catholic Church Melbourne, FL, tobin2@live.com, Melbourne, FL.

Tobin, E., 2017b, Introduction to the Creed (C 185-197) (Rcia). The mystery of God (C 198 267, Usc Ch. 5), tobin2@live.com, Melbourne, FL. 